\title{
Architectural Travelers: The Role of Field Trips in Spatial Design Education
}

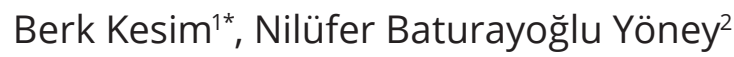 \\ ${ }^{1}$ Department of City and Regional Planning, Faculty of Architecture, Abdullah Gul University, Sümer Campus, 38080 Koca Sinan, \\ Kayseri, Turkey \\ 2 Department of Architecture, Faculty of Architecture, Mustafa Kemal University, Tayfur Sökmen Campus, Serinyol, 31060 \\ Antakya, Hatay, Turkey \\ * Corresponding author, e-mail: berk.kesim@agu.edu.tr
}

Received: 30 June 2021, Accepted: 09 November 2021, Published online: 13 December 2021

\begin{abstract}
Architectural design and its education are physio- and socio-spatial activities. In other words, creating space is concerned with understanding the physical as well as the social/cultural context to produce meaning and values beyond determining and answering the right questions. Informal learning environments have always been an integral part of the profession even before its formal definition. Experiential learning or field trips play a significant role in architectural and spatial design education, yet procedural aspects of designing such a journey have not been discussed by educators regarding active and informal learning. This paper aims to understand the role of field trips and re-discover how they contribute to spatial design education at undergraduate level through the processes of learning by doing and research by design / design by research. The field trips, or the context, are discussed with a three-fold focus as an interdisciplinary design process: (1) Understanding the study field from macro to micro scale; (2) Experiencing and observing the society, culture and daily life; (3) Comparative studies through visits to buildings with similar programs. Case studies with local, national and international/foreign contexts from design studios of primary and secondary cycles are presented in order to illustrate this process.
\end{abstract}

Keywords

architectural education, architectural design studio, experiential learning, informal learning environments, field trip

\section{Introduction}

Architects cannot do or build with what they have learnt; instead, learning by doing and building. Informal learning environments have always been an integral part of the profession, even before the formal definition of its education. Field trips are the basic instrument of informal learning activity in architectural design education, which lets the individual gather actual experience.

Architectural design education is a journey that never ends for a dedicated designer. Instead of being a tourist in this journey, the architect is a traveler who takes the responsibility of building on behalf of others, leaving traces of his/her own professional experience. Here, "building" is not just a physical but also a socio-spatial act. Being a traveler or a tourist is behaviorally different. The traveler has a certain intended purpose while the tourist behaves in a random manner, based on other types of input (Koberg and Bagnall, 1972:p.104). The architectural traveler, unlike the tourist, has a field trip or journey besides a mere touristic site visit.

Even though field trip is an essential part of the learning process for the architectural studio, just as important as learning in the studio itself, designing an architectural journey is not discussed in educational science regarding active or informal learning environments. This article aims to question the learning procedure of field trips for undergraduate architectural design education. Ultimately, a threefold rule set and a procedure are proposed for field trips in architectural design studios.

\section{Field trip: an adventure for architectural design}

Field trip or journey has been an integral part of architectural education at least since its formal definition in the $19^{\text {th }}$ century. It is known that Sinan, the imperial royal head architect of the Classical Ottoman Period during 
the $16^{\text {th }}$ century, benefited from his travels throughout the imperial lands with the army as much as from his training before his recruitment and at the imperial court (Sözen et al., 1989:pp.57-61). Beaux-Arts education and design methodology, outlined in Durand's and others' publications at the beginning of the $19^{\text {th }}$ century, relied heavily on architecture(s) of the past ages. The Grand-Prix of the Academy of Fine Arts in Paris was a one-year study trip to Rome for the student graduating as the valedictorian in architecture (Levine, 1984). Future works of some of the winners, such as Labrouste and Duban, bear witness to this journey's value.

Similar traditions continued into the $20^{\text {th }}$ century. Le Corbusier's Voyage d'Orient (1910-1911) is among the most famous instances of these architectural journeys, and its contribution to this unschooled architect was visible in his later works (Vogt, 2000:pp.32-45; Fig. 1). In a journey of five months, Le Corbusier made over 300 drawings, took over 500 photographs, and filled six notebooks (Frampton, 2001:p.13). He wrote, "The impressions, I confess, were staggering, unexpected. Slowly they began to seize me ..."; thus, beginning to understand and appreciate Istanbul, a city alien to Le Corbusier, took at least three weeks (von Moos, 2009:p.33). His drawings are reminiscent of sketchbooks collected at the end of field trips or studio work in architectural education.

Owen (2007) identifies some of the characteristics of design thinking as opposed to scientific and other types of thinking. Qualities including inventiveness "within the frameworks of human-centered and environment-centered measures", ability to mentally and physically visualize ideas, "optimistic and proactive ways of working", bias for adapting solutions "to fit the needs of users uniquely" and "to fit users' evolving needs", multifunctionality or keeping "the big picture in mind while focusing on specifics", systemic vision and holistic thinking, being "a specialist in the process of design, but a generalist in as wide a range of content as possible", ability to use various language(s) - visual, mathematical and verbal - as tools, affinity for teamwork or working "closely with other designers and experts from other fields", reaching solutions that "combine the best of possible choices", flying "to the outer reaches of what can be conceived" while tethered "to ways that the conceivable might be realized", and "structural planning" of "methods for a complete range of planning tasks covering ways to find information, gain insights from it, organize it optimally for conceptualization, evaluate results and communicate a plan to the public and follow-on teams in the development process". These skills and abilities are learned "tacitly" in design schools in the process, through the experience of design rather than becoming separately and consciously taught parts of courses and programs.

As suggested by Owen (2007) and other authors, design, and in particular architectural design, is a humanand environment-centered activity. It is based on sensing and understanding, analyzing, evaluating and synthesizing different types of information collected from different sources. The city/site is one of these parameters to be internalized and then externalized or expressed in the project/ product. Architecture students tacitly learn how to achieve this through studio work and by doing, first with their studio instructors and then on their own. The field trip forms a part of this process. The field trip and the activities connected to it are also useful for endorsing teamwork and collaboration, which is another skill that needs to be developed for design activity. There is no single way of organizing field trips; there may be many options and opportunities for different programs. However, there may be appropriate ways of doing it in terms of the architectural design studio. This article tries to discuss planning field trips through several design studio experiences.
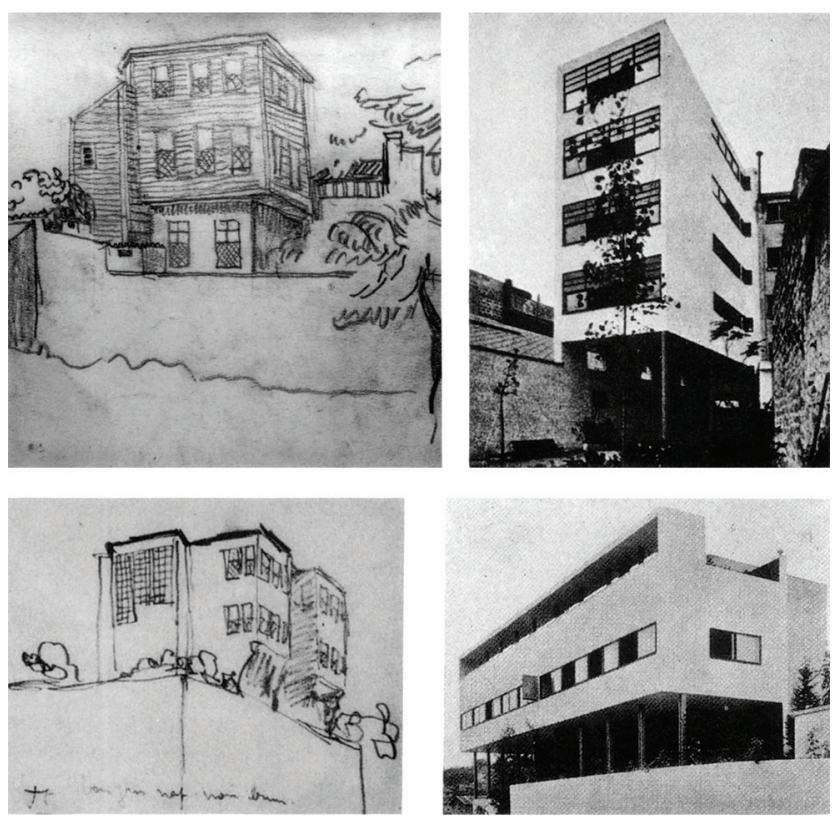

Fig. 1 Le Corbusier, sketches from Voyage d'Orient (1910-1911) compared with his work in the 1920s: Traditional houses with projections on the Golden Horn or the Bosphorus in Istanbul and the Salvation Army Building (1926; top right) and one of the houses at Weissenhof Siedlung (1927; bottom right). (Source: Vogt, 2000:p.45, images 45 and 46; reproduced under license CC BY-NC-ND 4.0) 


\section{Architect's journey}

Architect's journey to the field of study is a purposeful adventure in the informal learning environment. The journey consists of both planned and unplanned exploration. Unplanned happenings are desired as much as the planned ones, in that the field trip is a semi-planned activity and includes unplanned happenings. The field trip as an adventure has a unique behavioral pattern in the potential environment (Anderson, 1978).

Erving Goffman (1963; 1967) divides interaction behavior in public places into two: Focused Interaction and Unfocused Interaction ${ }^{1}$. Focused Interaction is situational behavior for planned activities. It is a self-conscious involvement in the environment through engagement and encounters. On the other hand, Unfocused Interaction is a random behavior for unplanned happenings. It is an unselfconscious involvement in the environment. Goffman (1967:p.169) emphasizes the vital necessity of Unfocused Interaction by stating that "... the individual [architect] is always in jeopardy in some degree because of adventitious linking of events, the vulnerability of his body, and the need in social situations to maintain the properties. It is, of course, when accidents occur - unplanned impersonal happenings with incidental dire results - that these sources of fatefulness become alive to us. But something besides accident must be considered here." Architectural travelling is a planned adventure consisting of both situational and random activities. Being neither a local inhabitant nor a tourist, the traveler's behavior is a distinct way of involvement in the built environment (Fig. 2). According to Koberg and Bagnall (1972:p.104): "It is the quantity and quality of the side trips which separate the tourists from the well-seasoned travelers in the world of problem-solving. The more exercises in the development of skills, knowledge and attitudes experienced along the way, the more meaningful will be the travelog [Travel Log] in the end."

\footnotetext{
1 "The communicative behavior of those immediately present to one another can be considered in two steps. The first deals with unfocused interaction, that is, the kind of communication that occurs when one gleans information about another person present by glancing at him, if only momentarily, as he passes into and then out of one's view. Unfocused interaction has to do largely with the management of sheer and mere copresence. The second step deals with focused interaction, the kind of interaction that occurs when persons gather close together and openly cooperate to sustain a single focus of attention, typically by taking turns at talking. Where no focused interaction occurs, the term unfocused gathering can be used. Where focused inter- action occurs, clumsier terms will be needed." (Goffman, 1963:p.24).
}

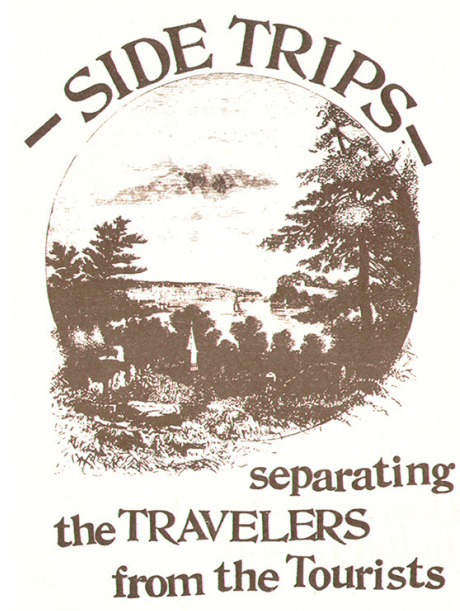

Fig. 2 Travelers vs Tourists (Source: Koberg and Bagnall, 1972:p.110)

An architect's journey is a designer's research through self-experimentation. It is a particular way of analyzing the site through instantaneous and individual spatial involvement. The essence of traveler's experience stems from the pragmatic behavior of the individual in the built environment ${ }^{2}$. The important point here is that the subjective experience of an observer/architect is not a rational disadvantage but provides cognitive and creative richness in design research.

Likewise, the architect must design the journey/field trip in as much as the project itself in terms of (1) Scale, (2) Sense and (3) Scope. The Scale of the journey sets the frames of reference for the project site in the urban environment. Assessment of the study field from macro to micro scale is crucial for designating the boundaries. The Sense of the journey sets the boundaries in the content and the extent of the field trip. The project site provides an all-encompassing source of experience, including various aspects of society, culture, history, politics, landscape, and urbanism. These may vary in any instance throughout the 24/7 daily-life experience. Sensing the spatial dimension comes before the focused experience of understanding, and no site visit could be limited to merely focused interaction; sensing the space and place in a non- or sub-conscious manner is just as important as understanding it consciously. As the author of the future project, the architect designates the journey in terms of dimension and observation in the field and should make the time spent there worthwhile. The Scope of the journey sets the boundaries of inspiration in the architect's

$\mathbf{2}$ It should be noted that field experience/research is objective because it is an actual individual experience. Pragmatically, any research would not be more actual than that. 
upcoming project. The journey should not be restricted to the determined location; the architectural traveler may also look for inspiration in similar project areas in different places or relate the project idea through analogy. However, if inspiration leads to duplication due to the students' inexperience, it may restrict creativity. The Scope should be determined before the field trip because each station in the journey affects the project.

Eventually, the architect's journey is the only possible actual experience before designing the project. There would not be any other possibility to involve real-life experience until the project's completion. Therefore, it is crucial to design the student architect's journey as attentively as the studio project itself and as an integral part of the process.

\subsection{The scale: architect's journey in the urban environment}

The architect usually begins the journey in the urban environment where the Scale is the main issue. The architectural journey must establish a common path between the architectural and urban scale because the project area is a part of a city. "The parts and the whole were rather in balance, neither claiming priority" (Arnheim, 1969:p.125).

The urban environment is a complex playground partially designed by architects and urban planners, with a holistic design approach. That is to say, we expect architects to relate to urbanism in architectural design studios and vice versa. The paradox here is based on the fact that actual site visits could never be enough for comprehending the whole urban experience. Therefore, the Scale of the architectural journey ought to be designed as well.

In this part of the study, the results of three different studios conducted on an urban scale are analyzed. Accordingly, the relationship between architecture and the city is questioned, and the most accurate studio operation is sought.

In architectural design education, participants need to grasp two complementary design perspectives. These are the urbanism-based relatively holistic perspective (wholes to parts) and the architecture-based relatively incremental perspective (parts to wholes). Therefore, in the first two studio exercises, the complementing perspectives were tried simultaneously with the same study group in the same field of study. First, a relatively holistic urban design approach based on urbanism, and then an architecture-based relatively partial urban design approach was applied. In the third studio, the elemental design approach as a combination of the two methods was generated from their inferences (Fig. 3).
In the first case, a relatively holistic design approach based on urbanism was applied in the studio program. Participants were asked to prepare an architectural design project at the scale of urbanism. In this exercise, a much wider project boundary than the architects are accustomed to is preferred so that participants may understand the needs of a city while building a part of it. The selected site was a part of the city that the participants lived. Thus, each participant had a certain awareness of the characteristics of urbanization. They preferred to design architectural and urban design separately and, they later combined the two different designs. This method created left-over spaces, and adaptation problems occurred in the transition from architectural to urban design scale (Fig. 4). The students were eager to begin designing their building inside the

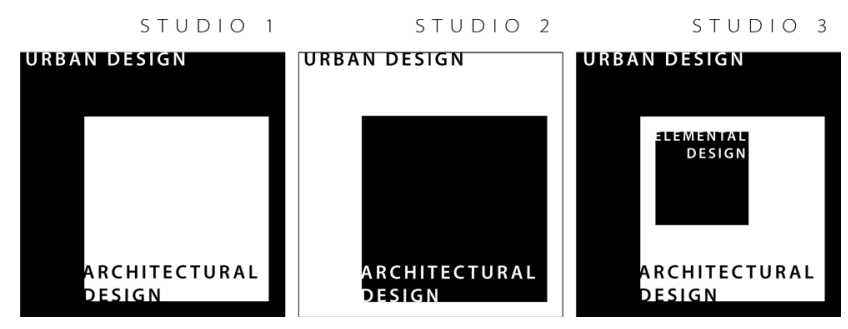

Fig. 3 A Schematic View of Studio Methods tried in Scales of Architect's Journey (Source: illustration by Kesim, B., 2021)

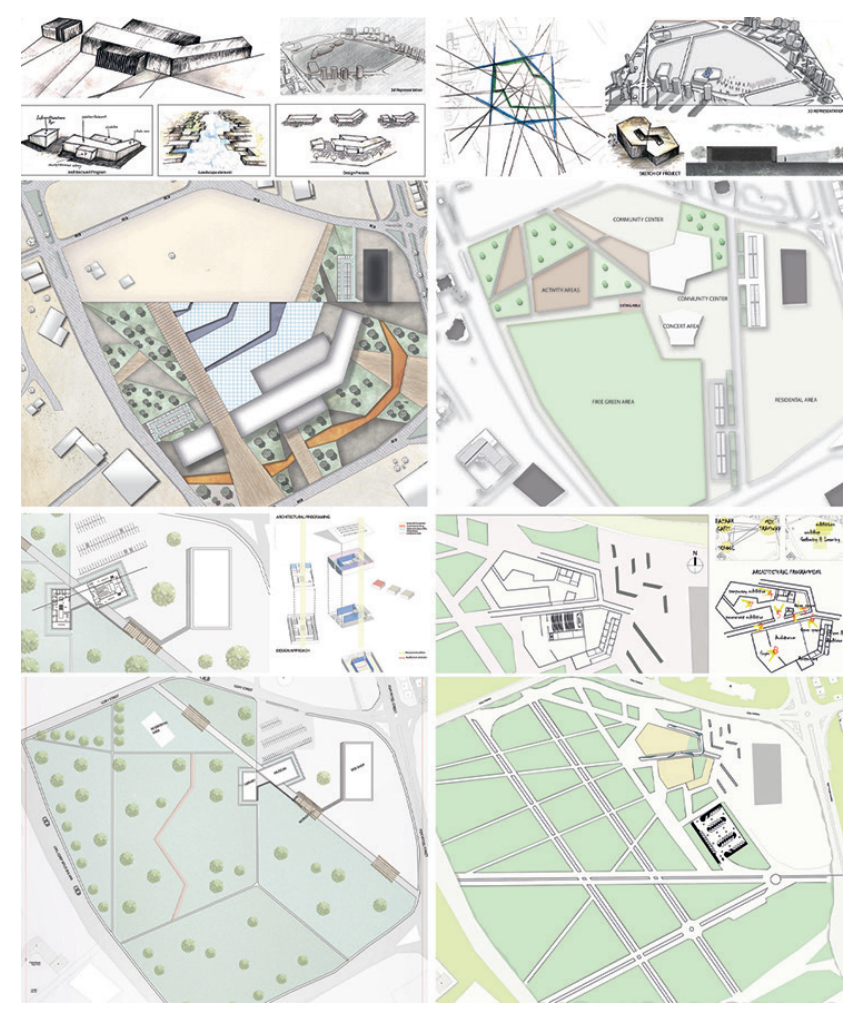

Fig. 4 Urbanism Based Relatively Wholistic Design Approach (Source: AGU Department of Architecture, ARCH301 Architectural Design Studio, Fall 2018-2019) 
given lot, claiming that extending the site analyses phase would detract time from architectural design. The problem here is that the architectural proposal became a more prominent contribution than the urban design. Thus, the boundary of architectural design was defined by the project area, which is the "frame of reference" of this project (Günay, 2007). However, the frame of reference is more than a boundary. It indicates that the project has physical references inside the area and has an impact beyond this boundary. An architect is also responsible for this frame of reference, according to which the architect's journey must be designed in the urban environment. At the end of the studio work, even though there were problems of scale, the exercises enabled students to understand the city, its scale and the importance of their architectural entity in the urban environment they created.

In the second case, an architecture-based relatively incremental urban design approach was applied in a program parallel to the previous studio work. The same participants were asked to design an urban project for the same site without being given a predetermined boundary. The students defined the frames of reference and created the relevant design questions from the urban image constituted through the field trip. In the initial exercise, they tried to generate concept designs for the city's morphological problems using metaphoric and analogical methods independent from the site. Starting from the smallest architectural units, they designed a whole urban structure, going from the parts to the whole. Then, they tried to adapt the conceptual urban structures to the site. Although the designs produced in the studio were rich and morphologically diversified, they remained abstract and conceptual (Fig. 5). Participants had difficulties in adapting the abstract architectural structures to the site and locating them. However, it was observed that the participants were more creative in design solutions compared to the first case, using a design approach proceeding from Parts-to-Whole. It could be inferred that architecture students are prone to designing from parts and can design much faster and more effectively this way.

As an outcome of these two studio experiences, it may be proposed that the design exercises on Parts-to-Wholes \& Wholes-to-Parts, or in other words, from urban scale to architectural and from architectural scale to urban, must be a part of the architectural studio experience in various combinations to increase the professional's "intelligence of perception" and overcome the paradoxes originating from scale (Arnheim, 1969:p.13).

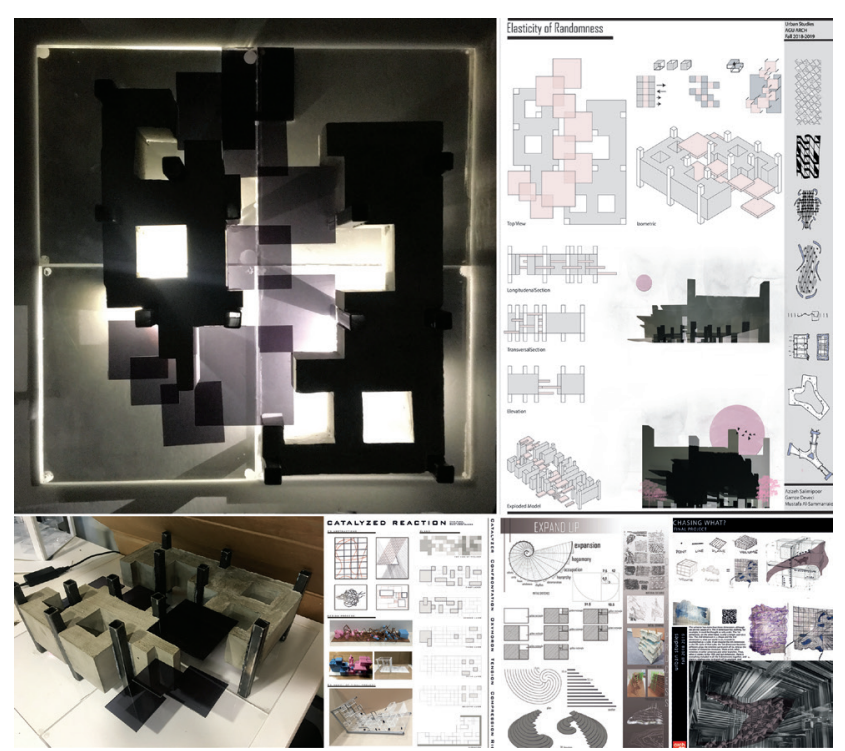

Fig. 5 Architecture Based Relatively Partial Design Approach (Source: AGU Department of Architecture, ARCH311 Urban Studies, Fall 2018-2019)

Problems regarding the scale difference between architecture and urbanism may be eliminated by combining the positive aspects of the two methods. The positive and negative outcomes of the two different studio programs help develop intelligence of perception in architectural education. By using the correct method in the correct frame of reference, it may be possible to reach a higher intelligence of perception in the built environment.

Thus, a combined method was applied in the last example with different architecture students at the same skill level. Unlike the first two cases, the project site was selected in a different city. The instructors proposed pre-identified subfields, but the students were required to design their frames of reference by themselves. The studio operation had two phases: The first phase was composed of problem formation and site selection in the urban macro form. During the journey, participants generated an analytical framework in the urban environment by researching and producing design concepts, sketches, and drafts. They were also responsible for selecting the most inspirational site for their final project. The second phase concentrated on in-situ analyses and design in the selected sites. Participants were asked to generate patterns from their morphological analyses. After the journey, generated patterns were used to make concept models and finally, to produce an urban public space design proposal for the selected site. The design method was shifted during the studio operation to use the positive aspects of Parts-to-Wholes \& Wholes-to-Parts approaches to benefit the students' intelligence of perception, based on the results 
of the first two cases. Throughout the first phase, all research and design activities were directed from wholes (urban form) to parts (districts and plots). In the second phase, all research and design activities were directed from parts (morphologic inspirations/analysis) to wholes (districts and plots).

At the end of the studio, although architects tend to get lost while designing at an urban scale, it was observed that a preliminary exercise on the whole urban form created a certain focus, and architectural design proposals provided more compatible results with the urban context in further stages (Fig. 6). Moreover, participants tended to work more devotedly when they knew they could actively influence the studio program. The flexibility of choosing a site provided a reason for the participants to analyze and better comprehend the city.

After all, the claim is that the field trip must be understood as a part of the creative studio operation and designed carefully by the instructors so that the potential of informal learning environments may be used effectively during the architect's journey in the urban environment through creating, researching and designing. Architects must also have an idea about the whole (city) and the parts (architecture) they design. Therefore, considering the Scale, while the analytic studies are based on a deductive approach at the start, an inductive approach gives creative results for the following urban and architectural design phases in the architectural studio.

\subsection{The sense/context: architect's journey as site experience}

The Sense denotes a combination of Focused and Unfocused Interactions related to the project site and its environment. Architectural design education includes developing a feeling and an understanding of the site through the Scale and the Sense, acquiring both conscious and unconscious experience in context. That is why a directed site visit forms an integral part of each studio. It is also known that designing in the city where the students live is easier than creating a similar experience for a different urban environment. The Sense is related to living in a given setting, even if limited to a few days.

In three consecutive years, the same second cycle studio theme was held in three different contexts/environments. In 2017 the site was abroad in Athens, Greece, in 2018 in Kayseri, Turkey, the city in which the students live in but at an archaeological site on the urban periphery that they have not experienced previously, and in 2019

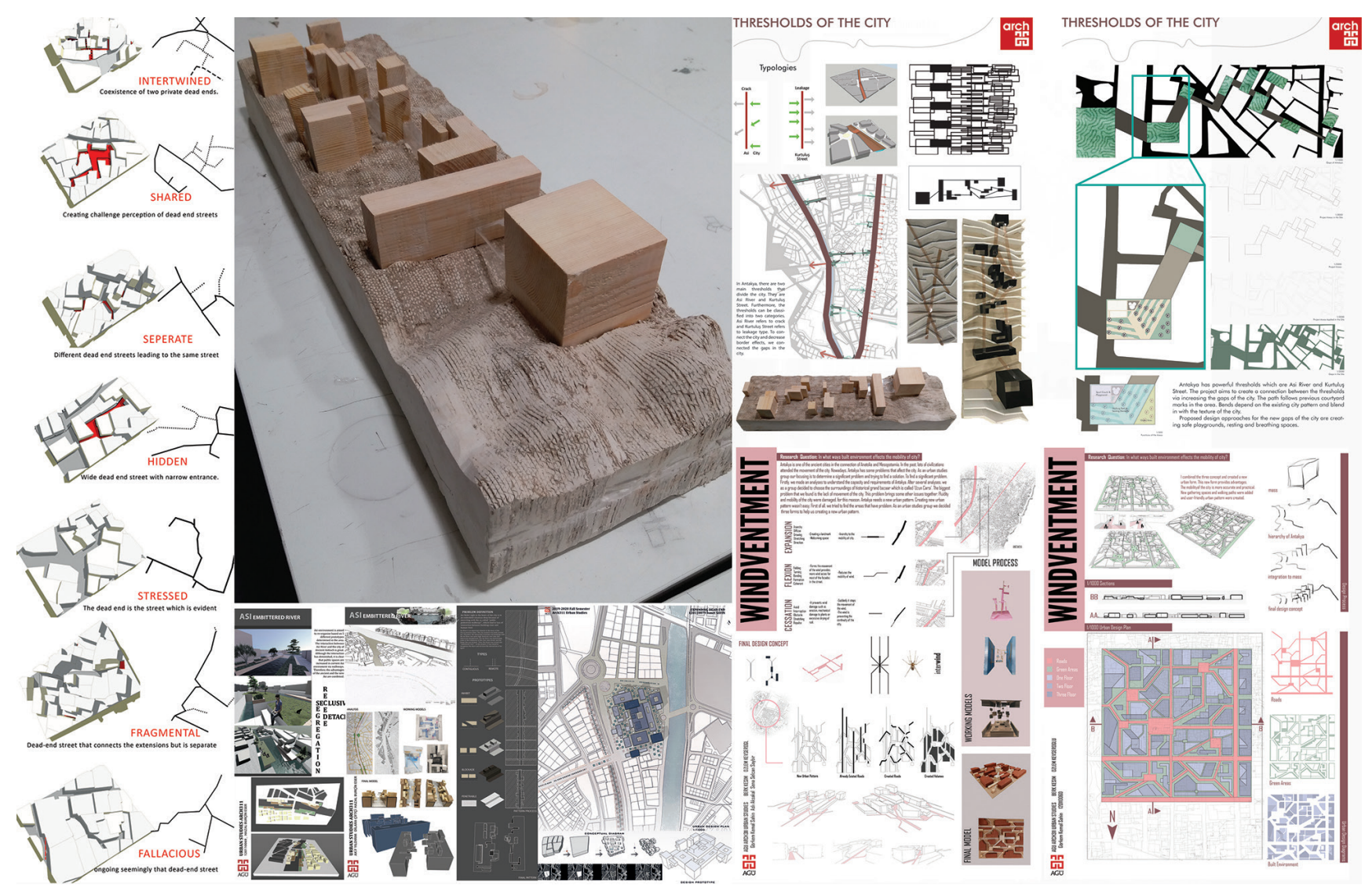

Fig. 6 Combined Method (Source: AGU Department of Architecture, ARCH311 Urban Studies, Fall 2019-2020) 
in Antakya / Antioch ad Orontes, Turkey, a different city, with which the students were not familiar. Sensing these cities or locations/sites was a unique experience in each case. It was also a series of experiments for the studio instructors to test how the site and field trip experience related to what was reflected in the work.

The field trip includes both formal and informal behavior so that the studio participants' experiences are related to the activities in the field. The instructors need to define several joint group activities while providing free time for the participants to discover their surroundings independently. The students are expected to analyze their experiences in any environment and evaluate them in their design. In this context, the environment becomes larger than that in the Scale and includes all of the city and its periphery, even those parts not directly related to the project site. This is not only a physical or morphological study but should include all aspects of daily life.

One of the most common tools is the sketchbook. All art and design disciplines utilize a sketchbook to generate, record and collect new ideas; some or even most of these may prove useless or redundant in the end, but the act of collection is important as design thinking requires a certain degree of trial-and-error. One further use of the sketchbook in the architectural design studio is transforming sensory experience and abstract ideas into a more cognitive phase of understanding and giving them physical/morphological form (Fig. 7). It is also interesting for the instructors to see what physical images appear striking to the students and whether these correspond to their images of the site and the urban environment, and similarly, how different students interpret the same site(s) or built environment(s). Drawing, more than photography, is more illustrative in perceiving the mechanisms of sensing and understanding. It is also more related to the human scale as opposed to photos. In this context, the artistic quality of the drawings is irrelevant compared to the ideas illustrated by them.

In correlation with the three studio experiences described above, trips were made with the students to several important sites and buildings in and around the city (Fig. 7). The collective experience from such sites visited with the instructors is different from the individual experiences the studio participants gather on their own. The instructors' leadership provides the necessary know-how while the individual visits become less focused and more sensory experiences, which evolve into understanding and design creation in the studio. Ideally, the participants must

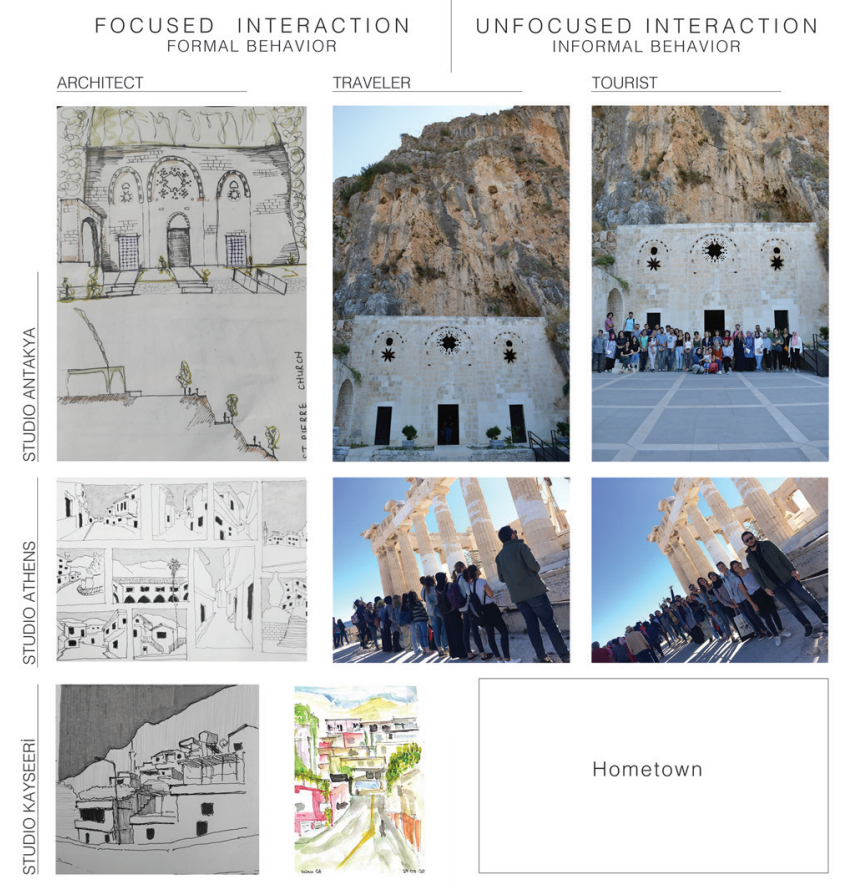

Fig. 7 Images of the studio project sites (Source: AGU Department of Architecture, ARCH401, fall 2019-2020 (Antakya), Fall 2017-2018 (Athens), Fall 2018-2019 (Kayseri))

experience the sites both collectively and individually, with focused and unfocused interactions as they do in the city and physical environment where they live.

Individual and unfocused experiences are harder to document visually. They are informal events, in which the students, on their own or with their friends, are involved in different types of activities, such as sightseeing and daily-life encounters, like eating, shopping and recreation, sensing the city and its environment on workdays and holidays, day and night. This is more important for the students in sensing and understanding a different and new city and its cultural, socio-economic, historical and political dynamics than research, reading and analyses. Ideally, they need to try and live like a local and sense and collect contextual experience in a short period.

The period spent in an unknown city and physical and social environment is also determinant in the quality of the field-work. As the period allocated in the architectural design studio for this purpose is relatively short, from a few days to perhaps a week, the instructors use their research input or provide input from local research to hasten the sensing process. These are usually in the form of lectures and guided site visits. The field trips, in each case, were also supported by lectures from guest instructors, who are directly related to those places in terms of their life and research. However, in almost all design fields, 
designers accept that their sensing and understanding of the client's needs (s) and site(s) would be limited. They try to make the most of the allocated time. Using field time efficiently and to the point becomes another skill acquired in design schools.

To summarize, what is discussed in terms of Sense may be reduced to the question: "How to behave on a field trip: to be an architect, a traveler or a tourist?" Architects sometimes behave like a professional and sketch, sometimes they act as a traveler and take photographs, and at other times they become just tourists. In each case, sensing the city/location/site is a unique experience in that the architectural traveler must be all at the same time.

\subsection{The scope: architect's journey into related projects and activities}

The Scope may include both journeys and additional branches of the journey, which are circuitously related to the project site and subject. These may include practical activities as well as visits to conceptually comparable projects and sites. The 2020-2021 pandemic brought about an additional choice: Rather than visiting the site, information about the site, in terms of Scale, Sense and Scope, may be gathered on secondary visual and written sources, ranging from the world-wide-web to printed material and accounts of people who are familiar with the site. For architectural design, this is a problematic situation: Architects have come to understand that understanding an architectural space may only be attained through sensory experience (McCarter and Pallasmaa, 2012). Therefore, both comparable and related projects were better visited than only analyzed through visual and written sources. To understand a visited example in architectural terms, instructors need to provide visual architectural information during the visit, such as drawings and old photographs.

The situation enforced by the 2020-2021 pandemic, in other words, not being able to visit the site or similar sites at all, creates a dilemma. On the one hand, secondary information could provide a tool for design; it may be interesting to see the result of this approach. We might find that making no journey at all increases our creative power. However, the generally accepted approach is to experience the site(s) and achieve this by making the most of the time. Thus, an unplanned field trip is unacceptable in terms of the design studio.

The field trip for the third architectural design studio included visits to a building conceptually comparable to the subject and a site also conceptually related to the project theme, both published and well-known outstanding examples of architecture in Turkey. These were Boğaziçi University's Gözlükule Research Centre (restoration project by Saadet Say1n, 2017) in Tarsus and Karatepe-Arslantaş Archaeological Site and Buildings (achitectural design by Turgut Cansever, Franco Minissi and Nail Çakırhan, 1961). The notes and sketches of the students from these two sites are different in their depiction of architectural concepts such as site and context, function and use, spaces, elements and details (Fig. 8). In the previous studio, a similar trip was made to the Kaman Kalehöyük Archaeological Centre and Museum. This is the base of the Japanese Institute of Anatolian Archaeology, directed by Professor Sachihiro Omura (Fig. 8), organized by Professor Fikri Kulakoğlu, the director of the Kültepe Kanesh-Karum Archaeological Site, where the students were working for the studio. Such visits, letting the students experience the spaces and

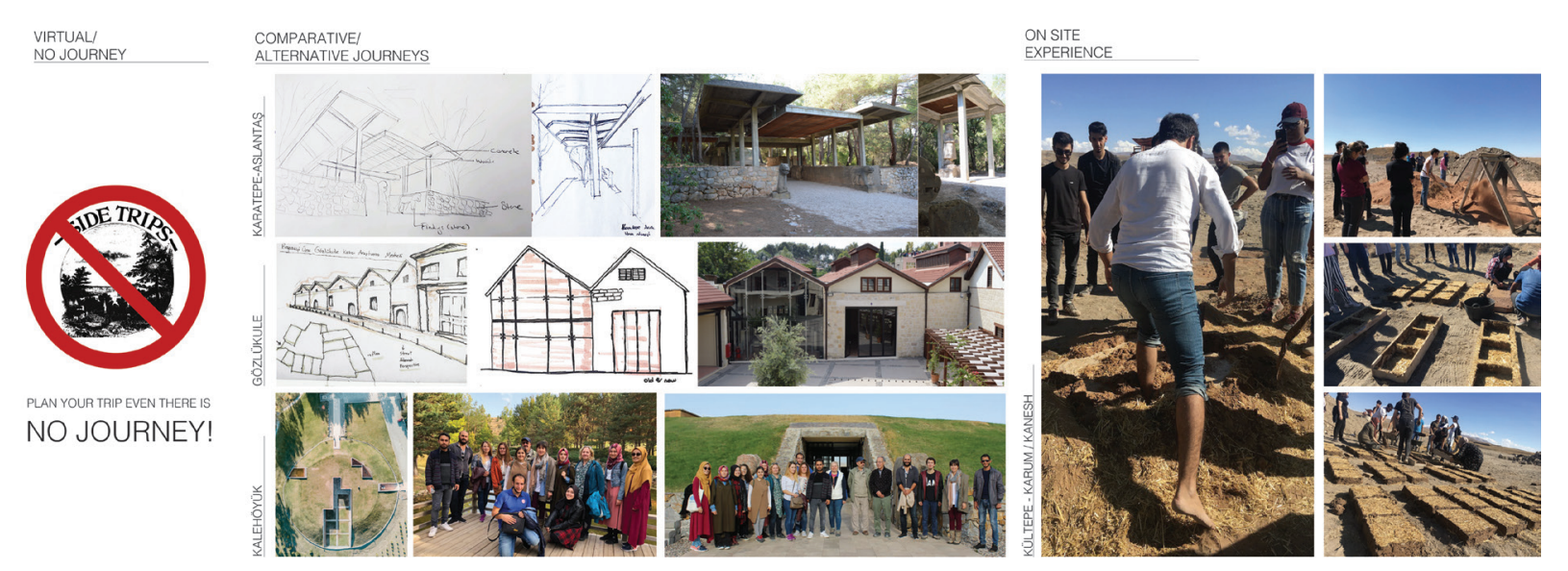

Fig. 8 The Scope of the architect's journey (Source: Images of visits to other sites - Gözlükule Research Center, Tarsus (2019), Karatepe-Arlantaş Archaeological Site, Osmaniye (2019) from the architectural studio students' field trip sketchbooks, AGU Department of Architecture, ARCH401, fall 2019-2020; visit to Japanese Institute of Anatolian Archaeology in Kaman Kalahöyük (2018), AGU Department of Architecture, ARCH401, fall 2018-2019; and AGU-Arch Kerpiç/Mudbrick Workshop at Kültepe-Kanesh/Karum Archaeological Site, Kayseri (2019)) 
buildings independently and in a group, are expected to inspire their projects while providing first-hand knowledge of a good practice example.

Also, in connection with the second studio, whose site was chosen at a Bronze Age archaeological site, KültepeKanesh/Karum, on the Kayseri urban periphery, the participants were involved in a workshop to learn and experiment with the primary building material of the original site kerpiç/mudbrick (Fig. 8). This experience was planned to introduce them hands-on to a material that they only saw in lectures. It was also expected to facilitate inspiration for their design projects, located near the same site and functionally involved with it.

The paradox in the Scope of a journey is in making no journey or a virtual journey, such that the visiting experience in alternative/comparative sites becomes an "in-direct" experience for collecting inspiration. Increasing the range and type of experiences would undeniably positively affect the studio's work, and therefore, an architectural studio field trip must include them all.

\section{Conclusion}

The traditional Grand Tour has taken by the young men of means in the $17^{\text {th }}$ and $18^{\text {th }}$ centuries, and not necessarily only by those studying architecture, was a method of general education through experience. The Grand Prix of the Beaux-Arts school in the $19^{\text {th }}$ century was an integration of this concept into architectural education. Benefits of traveling were illustrated in the Antiquity, Middle Ages and the Renaissance Period design and construction examples both in the West and the East. Many architects moved from city to city or were specially invited to build in different places, disseminating their experience. This tradition continued in the $20^{\text {th }}$ century, as illustrated by many published and unpublished examples. For instance, I. M. Pei's request from his client to travel and study Islamic architecture when he was asked to design the Museum of Islamic Art in Doha, Qatar. He was almost 90 years old and embarked on a "journey of discovery" from India to Spain (Fairs, 2008). Pei identified the $13^{\text {th }}$-century ablution fountain of the $9^{\text {th }}$-century Ibn Tulun Mosque in Cairo as his inspiration in design (VisitQatar).

Staying long in a place and learning the ways of the people was important for Le Corbusier to appreciate. He was not an ordinary traveler either, but a designer, an architect who opposed Théophile Gautier's notion that Turkish timber houses were no more than "poultry coops" in the following words: "... the konak, is an architectural masterpiece" (von Moos, 2009:pp.33,324). Le Corbusier refused to continue his education in an architecture school and instead studied buildings that he believed were relevant to the development of western architecture, including Islamic buildings. While his rejection of a formal education in architecture was at least partially based on Édouard Schuré's teachings and his "critique of the antagonism between the Christian Church and the University", Le Corbusier's interpretation of the "dialectical interaction between rationalism and idealism" in architecture, which later opened the way for his approach to modernism, was based on the buildings he studied in detail during his travels, including Notre-Dame in Paris, Hagia Sophia and several mosques in Istanbul (Rabaça, 2015).

Today the rise of information technologies has made the visual experience much easier to reach. However, these materials, including images, projects, photographs and videos, and written sources, are not the same as a focused group or individual experience of architectural or urban space. The studio field trip is an especially planned activity, forming an essential part of the education. Its planning and the intended focused group experience separate it from other informal types of individual architectural travelling.

This paper's ultimate proposal for architectural studio travelers is a three-fold rule set based on the Scale, Sense and Scope of the journey to improve the field trip experience in design education. The checklist is recommended as a control mechanism to ensure that the program includes all three steps identified in this article (Fig. 9).

The first paradox in the Scale of the journey is to decide whether to design from Parts-to-Wholes or Wholes-toParts. The proposal is to start analyzing/working on the city but designing on-site. The second paradox in the Sense of the journey is whether to travel like a professional architect or a visitor trying to blend into local life. The proposal is to combine both approaches. The third and final paradox in the Scope of the journey is whether to make a traditional field trip to the site or to research virtually without any journey and combine either of these with visiting alternative/comparative sites. The proposal is to start working and creating before the journey, then testing the ideas in the field and continuing the design process after the field trip. The alternative/comparative field trips are recommended after the site visit. In conclusion, an architect must be a traveler first and always needs to travel more. 
ARCHITECTURAL TRAVELERS CHECKLIST

\begin{tabular}{|c|c|c|c|c|c|c|c|c|}
\hline DIMENSIONS OF JOURNEY & $\underline{\text { PARADOX }}$ & & & & & & & \\
\hline SCALE & Designing from & Parts-to-Wholes & Analyse & Jork on the Whole Cit & & & $\square$ & \\
\hline & & $\begin{array}{c}\text { or } \\
\text { athoce }\end{array}$ & Ideate I & panism (Generate ar & n Idea) & & $\square$ & \\
\hline & & Wholes-to-Parts & Design & Site & & & $\square$ & \\
\hline SENSE & Focused Int. & $\begin{array}{c}\text { (Formal) Journey } \\
\text { or }\end{array}$ & Being & & Architect & Traveller & Tourist & Local \\
\hline & Unfocused Int. & (InFormal) Journey & Be all & IN the same body. & $\square$ & $\square$ & $\square$ & $\square$ \\
\hline & & & & AT the same time, & $\square$ & $\square$ & $\square$ & $\square$ \\
\hline & & & & ON the field & $\square$ & $\square$ & $\square$ & $\square$ \\
\hline SCOPE & & $\begin{array}{c}\text { Traditional Field-Trip } \\
\text { or }\end{array}$ & Create & before the journey & & & $\square$ & \\
\hline & & On-Site Experience & Test it & on the field & & & $\square$ & \\
\hline & & Comparative/Alternative Journey & Find & alternatives & & & $\square$ & \\
\hline & & Virtual/No journey & Search & more & & & $\square$ & \\
\hline
\end{tabular}

TRAVEL MORE

Fig. 9 Architectural Travelers Checklist (Source: illustration by Kesim, B., 2021)

\section{References}

Anderson, S. (1978) "On Streets", In: Anderson, S. (ed.) People in the Physical Environment: The Urban Ecology of Streets, MIT Press, Cambridge, MA, USA, pp. 1-11.

Arnheim, R. (1969) "Visual Thinking", University of California Press, Berkeley, CA, USA.Fairs, M. (2008) "Museum of Islamic Art by IM Pei", Dezeen, [online] 8 December. Available at: https:// www.dezeen.com/2008/12/02/museum-of-islamic-art-by-im-pei/ [Accessed: 21 June 2021]

Fairs, M. (2008) "Museum of Islamic Art by IM Pei", Dezeen, [online] 02 December 2008. Available at: https://www.dezeen. com/2008/12/02/museum-of-islamic-art-by-im-pei/ [Accessed: 21 June 2021]

Frampton, K. (2001) "Le Corbusier", Thames \& Hudson, London, UK.

Goffman, E. (1963) "Behavior in Public Places, Notes on the Social Organization of Gatherings", The Free Press of Glencoe, New York, NY, USA.

Goffman, E. (1967) "Interaction Ritual: Essays in Face-to-Face Behavior", Doubleday, New York, NY, USA.

Günay, B. (2007) "Gestalt Theory and City Planning Education", METU Journal of Faculty of the Architecture, 24(1), pp. 93-113.

Koberg, D., Bagnall, J. (1972) "The Universal Traveler: a companion for those on problem-solving journeys and a guidebook to the process of design", William Kaufmann, Los Altos, CA, USA.

Levine, N. (1984) "The competition for the Grand Prix in 1824: a case study in architectural education at the Ecole des Beaux-Arts", In: Middleton, R. (ed.) The Beaux-Arts and the Nineteenth-Century French Architecture, Thames and Hudson, London, UK, pp. 66-123.
McCarter, R., Pallasmaa, J. (2012) "Understanding Architecture", Phaidon Press, New York, NY, USA.

Owen, C. (2007) "Design Thinking: Notes on its Nature and Use", [pdf] Design Research Quarterly, 2(1), pp. 16-27. Available at: https:// www.id.iit.edu/wp-content/uploads/2015/03/Design-thinkingnotes-on-its-nature-and-use-owen_desthink071.pdf [Accessed: 27 June 2021]

Rabaça, A. (2015) "The Philosophical Framework of Le Corbusier's Education: Schuré and German Idealism", In: Le Corbusier, 50 Years Later International Congress, València, Spain, pp. 1-19. https://doi.org/10.4995/LC2015.2015.671

Sözen, M., Saatçi, S., Çelebi, S. M. (1989) "Mimar Sinan and Tezkiret-ül bünyan", MTV Film Television Video Sanayi ve Tic, Istanbul, Turkey.

VisitQatar "Discover the Museum of Islamic Art", [online] Available at: https://www.visitqatar.qa/en/things-to-do/art-culture/museumsgalleries/museums/museum-of-islamic-art [Accessed: 21 June 2021]

Vogt, A. M. (2000) "Le Corbusier, the Noble Savage: Toward an Archeology of Modernism", MIT Press, Cambridge, MA, USA. https://doi.org/10.7551/mitpress/4180.001.0001

von Moos, S. (2009) "Le Corbusier, Elements of a Synthesis", 010 Publishers, Rotterdam, The Netherlands. 